\title{
Pediatrician Support for Families Seeking Quality Child Care
}

\section{Alice Sterling Honig}

Human Development and Family Science, Syracuse University, 182 White Hall, Syracuse, New York 13244, United States

\begin{abstract}
Pediatrician scan expand their services and positive supports for young children's healthy development by helping families to find quality child care for their infants, toddlers, and preschoolers. Providing a one-page guideline - a summary of tips to look for in choosing child care provider(s) can help parents focus in on the essential relationship qualities they need to look for when searching for care - whether a family childcare or a group daycare facility. Pediatricians can boost parents' ability to focus on caregiver qualities. These are crucial to consider, beyond the family's need to decide about cost, location convenience, cleanliness, cheerful child furniture arrangements, and attention to child safety. The ten tips below provide parents with a brief checklist of what to look for when observing the quality of caregiver relationships and interactions with children in a facility they are considering for their own child.
\end{abstract}

\section{Ten Tips for Choosing a Quality Care Person for Your Child}

1. Caregivers act in loving ways with each child. They often smile at children. During the day, caregivers hug and cuddle children. They give backrubs to settle a restless little one at nap time.

2. Adults speak in reassuring kind voice tones with children.

3. Caregivers tune into the different temperament styles of each child in the group. Some children are easy going. However, some are intense and highly excitable; they get stressed quickly and need a patient calm adult to help them manage strong emotions. Other children act withdrawn, shy, and feel worried in response to new foods, playmates, or situations. Nurturing, perceptive caregivers tune into the unique temperament style of each individual child.

4. Caregivers read several times daily with the children, individually as well as at group time. When adults share reading 5 picture books daily, then children enter kindergarten having heard about 1.4 million more words compared with children who have never been read to.

5. Wise adults read body language and facial cues when children are feeling distressed, tired, angry, worried, scared, or lonesome. They try to understand behaviors that are puzzling or challenging. Then they figure out how best to build more positive trust so that the child feels understood, comforted, and able to comply more easily and get along better in the group.

6. Adults are generous language providers. Daily they find time to talk individually with each tiny child in back- and-forth exchanges that reflect their genuine interest in, and appreciation and respect for each child. They sing easy songs with children and encourage enjoyment of music and dance times, such as "Ring around- a -rosy" circle time while chanting with toddlers.

7. Teachers give specific praise to a child who is trying a new or difficult task. Instead of "Good job", they may say: "You really tried hard to fit all the train tracks together so that you could zoom your train on those tracks. “

8. Caregivers promote positive social skills in peer relationships. Gently they help a shy child find ways to enter into play with peers. They read stories about kindness and caring such as

\section{Publication History:}

Received: May 23, 2019

Accepted: August 15, 2019

Published: August 17, 2019

\section{Keywords:}

Quality child care, Child safety, Body language, Facial cues

"The little engine that could". In peaceful, cheerful ways, they encourage a feisty or boisterous child to wait more patiently for a turn at the side so the other children will then be more likely to feel friendly and comfortable in play with that child. Their remarks reflect children's happy feelings and also negative emotions - so children feel grownups truly understand them, even if sometimes a child feels frustrated or crabby.

9. Teachers provide a variety of play opportunities: sensory play ( at a water or sand table; gross motor play ( with space to run and jump and play catch with balls); small-muscle play ( with puzzles, pegboards, and wind-up toys), and art experiences (including, crayons, finger paint, play dough, and clay).

10. Adults provide outdoor time (when weather permits) each week so children can enjoy running, safe climbing, and are able to talk or even squeal and shout loudly more than when they are indoors. As well, care providers help children learn about and rejoice in nature-plants, trees, bugs, flowers, birds, squirrels, and earthworms. They arouse children's desires to be careful with the environment and kind with nature's creatures.

\section{Competing Interests}

The author declare no competing interests.

\section{References}

1. Grabmeier J (2019) A million word gap for children who aren't read to at home.

2. Honig AS (2002) Secure relationships. Nurturing infant/toddler attachment in early care settings. Washington, DC: National Association for the Education of Young Children.

3. Honig AS (2014) The best for babies. Expert advice for assessing infanttoddler programs. Lewisville, NC: Gryphon House

4. Honig AS (2015) Experiencing nature with young children. Awakening delight, curiosity, and a sense of stewardship. Washington, DC: National Association for the Education of Young Children.

"Corresponding Author: Prof. Alice Sterling Honig, Human Development and Family Science, Syracuse University, 182 White Hall, Syracuse, New York 13244, United States; E-mail: ahonig@syr.edu

Citation: Honig AS (2019) Pediatrician Support for Families Seeking Quality Child Care. Int J Pediatr Neonat Care 5: 155. doi: https://doi.org/10.15344/24552364/2019/155

Copyright: (c) 2019 Honig. This is an open-access article distributed under the terms of the Creative Commons Attribution License, which permits unrestricted use, distribution, and reproduction in any medium, provided the original author and source are credited. 
Citation: Honig AS (2019) Pediatrician Support for Families Seeking Quality Child Care. Int J Pediatr Neonat Care 5: 155. doi: https://doi.org/10.15344/24552364/2019/155

Page 2 of 2

5. Honig AS (2019) Choosing childcare for young children. In M.H. Bornstein (Ed.). Handbook of Parenting. The practice of parenting 5: 318-346.

6. National Institute of Child Health and Human Development Early Child Care Research Network (2002) Child care structure process outcome: Direct and indirect effects of child care quality on young children's development. Psychological Science 13: 199-206.

7. Sabol TJ, Pianta RC (2012) Recent trends in research on teacher-child relationships .Attachment and Human Development 14:213-231.

8. Sroufe LA (1983) Infant-caregiver attachment and patterns of adaptation in the preschool: The roots of competence and maladaptation. In Minnesota Symposia on Child Psychology 16: 41-83.

9. Vandell DL, Corasaniti MA (1990) Variations in early child care: Do they predict subsequent social emotional and cognitive differences? Early Childhood Research Quarterly 5: 555-572. 